\title{
Hosts of Raoiella indica Hirst (Acari: Tenuipalpidae) Native to the Brazilian Amazon
}

\author{
Cristina A. Gómez-Moya ${ }^{1}$, Talita P. S. Lima ${ }^{2}$, Elisângela G. F. Morais ${ }^{2}$, Manoel G. C. Gondim Jr. ${ }^{1}$ \\ \& Gilberto J. De Moraes ${ }^{3}$ \\ ${ }^{1}$ Departamento de Agronomia, Universidade Federal Rural de Pernambuco, Recife, PE, Brazil \\ ${ }^{2}$ Embrapa Roraima, Boa Vista, RR, Brazil \\ ${ }^{3}$ Departamento de Entomologia e Acarologia, Escola Superior de Agricultura 'Luiz de Queiroz', Universidade \\ de São Paulo, Piracicaba, SP, Brazil \\ Correspondence: Cristina A. Gómez Moya, Departamento de Agronomia, Universidade Federal Rural de \\ Pernambuco, Av. Dom Manoel de Medeiros s/n, Dois Irmãos, 52171-900, Recife, PE, Brazil. Tel: \\ 55-81-3320-6207. E-mail: crigomezmoya@gmail.com
}

Received: January 30, 2017 Accepted: March 7, $2017 \quad$ Online Published: March 15, 2017

doi:10.5539/jas.v9n4p86 URL: https://doi.org/10.5539/jas.v9n4p86

The research is financed by Coordination for the Improvement of Higher Education Personnel (CAPES)/ Program Student-Agreement Post-Graduate (PEC-PG) for the scholarship provided to the first author.

\begin{abstract}
The expansion of red palm mite (RPM), Raoiella indica (Acari: Tenuipalpidae) in Brazil could impact negatively the native plant species, especially of the family Arecaceae. To determine which species could be at risk, we investigated the development and reproductive potential of $R$. indica on 19 plant species including 13 native species to the Brazilian Amazon (12 Arecaceae and one Heliconiaceae), and six exotic species, four Arecaceae, a Musaceae and a Zingiberaceae. Values of the instantaneous rate of increase $\left(r_{i}\right)$ were initially estimated at 7, 14, 21 and 28 days after infestation of each species. Higher values of $r_{i}(>0.05)$ were determined on the Arecaceae Adonidia merrillii, Astrocaryum jauari, Cocos nucifera, Bactris simplicifrons, Mauritia flexuosa, Phoenix dactylifera and Socratea exorrhiza, and on the Heliconiaceae Heliconia psittacorum Sassy; these were classified as "potential primary hosts". Lower, but still positive values of $r_{i}(0-0.05)$ were determined on the Arecaceae Bactris maraja, Oenocarpus bacaba, Oenocarpus bataua and on the Musaceae Musa $\times$ paradisiaca (Prata variety); these were classified as "potential secondary hosts". Negative values of $r_{i}$ were determined for the remaining plants, i.e., the Arecaceae Astrocaryum aculeatum, Attalea maripa, Bactris gasipaes, Elaeis guineensis, Euterpe oleracea, Euterpe precatoria, and the Zingiberaceae Alpinia rosea; these were considered "non-hosts". Species with $r_{i}<0.05$ were considered not to be threatened by the RPM. Biological parameters of RPM were evaluated on the plant species with positive $r_{i}$ (except $B$. maraja) and two native species with negative $r_{i}$ (E. oleracea and E. precatoria). Mean developmental time ranged from 14.7 days on $C$. nucifera to 21.4 days on Musa $\times$ paradisiaca, showing a significant influence of the plant substrate. Immature viability, oviposition rate, net reproductive rate $\left(\mathrm{R}_{0}\right)$ and intrinsic rate of increase $\left(r_{m}\right)$ were affected by the plant species.
\end{abstract}

Keywords: Arecaceae, invasive species, red palm mite, instantaneous rate of increase

\section{Introduction}

The red palm mite (RPM), Raoiella indica Hirst (Acari: Tenuipalpidae), was described from specimens collected in India on Cocos nucifera L. (Hirst, 1924). This species had only been reported from the Eastern Hemisphere (Dowling, Ochoa, Beard, Welrn, \& Ueckermann, 2012) before its detection in the Caribbean area by Flechtmann and Etienne (2004). RPM is currently distributed throughout the Caribbean area (Kane, Ochoa, Mathurin, Erbe, $\&$ Beard, 2012), also reaching Mexico (North American Plant Protection Organization [NAPPO], 2009), Florida (Peña, Bruin, \& Sabelis, 2012), Venezuela (Vásquez, Quirós, Aponte, \& Sandoval, 2008), Colombia (Carrillo, Navia, Ferragut, \& Peña, 2011) and Brazil (Navia, Marsaro Jr., Silva, Gondim Jr., \& Moraes, 2011). In Brazil, RPM was first reported in the northern states of Roraima (Navia et al., 2011) and Amazonas (Rodrigues \& Antony, 2011); it was very recently reported in the northeastern states of Alagoas, Ceará and Sergipe, and in the 
southern states of Mato Grosso and São Paulo (Empresa Brasileira de Pesquisa Agropequária [EMBRAPA], 2015; Oliveira et al., 2016).

In the Eastern Hemisphere, $R$. indica has been reported on plants of only four genera of Arecaceae: $C$. nucifera, Phoenix dactylifera L., Dictyosperma album (Borg.), Areca sp. and Areca catechu L. (Navia, Morais, Mendoça, \& Gondim Jr., 2015). However, in the Western Hemisphere it greatly expanded its host range, being now known from 95 plant species belonging to 58 genera of eight families: Arecaceae, Cannaceae, Cycadaceae, Heliconiaceae, Musaceae, Pandanaceae, Strelitziaceae and Zingiberaceae (Carrillo et al., 2012; Vásquez \& Moraes, 2012). About $81 \%$ of the known host species belong to Arecaceae; all others belong to other monocotyledonous families (Carrillo et al., 2012). Reports of dicotyledonous plants (Apocynaceae, Fabaceae and Sterculiaceae) as hosts probably refer to mites found while in the process of dispersion to the actual hosts (Vásquez, Colmenárez, \& Moraes, 2015). About 65\% of the hosts reported in the Americas are species introduced from the Eastern Hemisphere; about a quarter of the reported hosts are plants native to the New World, especially South America (Carrillo et al., 2012). The following species native to the Brazilian Amazonia have been reported as hosts: the Heliconiaceae Heliconia bihai (L.) and Heliconia psittacorum Sassy, and the Arecaceae Attalea maripa (Aubl.) Mart., Bactris gasipaes Kunth, Euterpe oleracea Mart., Euterpe precatoria Mart. and Mauritia flexuosa L. (Gondim et al., 2012).

The objectives of this study were to determine whether selected plants of families Arecaceae, Heliconiaceae, Musaceae and Zingiberaceae commonly found in the Brazilian Amazon could serve as hosts for $R$. indica, including some species previously reported as hosts (H. psittacorum and the Arecaceae A. maripa, B. gasipaes, E. oleracea, E. precatoria and $M$. flexuosa), to confirm previous results indicating those plants as potential hosts, given the very common occurrence of these plants in northern Amazon.

\section{Method}

Plants evaluated in this study included 13 species native to the Brazilian Amazon, of which twelve Arecaceae (Astrocaryum aculeatum G. Mey., Astrocaryum jauari Mart., A. maripa, B. gasipaes, Bactris maraja Mart., Bactris simplicifrons Mart., E. oleracea, E. precatoria, M. flexuosa, Oenocarpus bacaba Mart., Oenocarpus bataua Mart. and Socratea exorrhiza (Mart.) H. Wendl.) and one Heliconiaceae (Heliconia psittacorum L.f); and six exotic species, of which four Arecaceae (Adonidia merrillii (Becc.) Becc., C. nucifera, Elaeis guineensis Jacq., and P. dactylifera), one Musaceae (Musa $\times$ paradisiaca L., Prata variety) and one Zingiberaceae (Alpinia rosea Elmer). The following species were introduced as control, for being already known as true hosts: $A$. merrillii, C. nucifera, P. dactylifera and Musa $\times$ paradisiaca. Seedlings of these plant species were obtained from Embrapa Roraima and commercial nurseries and natural areas of Roraima State, Brazil [Cantá $\left(02^{\circ} 36^{\prime} 36^{\prime \prime} \mathrm{N}\right.$ $\left.60^{\circ} 35^{\prime} 49^{\prime \prime} \mathrm{W}, 02^{\circ} 48^{\prime} 55.09^{\prime \prime} \mathrm{N} 60^{\circ} 39^{\prime} 05.7^{\prime \prime} \mathrm{W}\right)$, Boa Vista $\left(02^{\circ} 45^{\prime} 29.2^{\prime \prime} \mathrm{N} 60^{\circ} 43^{\prime} 54.7^{\prime \prime} \mathrm{W}\right)$ and São João de Baliza $\left.\left(00^{\circ} 57^{\prime} 03^{\prime \prime} \mathrm{N} 59^{\circ} 54^{\prime} 39^{\prime \prime} \mathrm{W}\right)\right]$. The seedlings were planted in $20 \mathrm{~L}$ polyethylene pots filled with a mixture of soil and cattle manure and irrigated manually once a day. Plants were about $0.2-1.1 \mathrm{~m}$ high and had 3-4 leaves.

\subsection{RPM Stock Colony}

Specimens of RPM were obtained from C. nucifera plants in Boa Vista $\left(02^{\circ} 45^{\prime} 29.2^{\prime \prime} \mathrm{N} 60^{\circ} 43^{\prime} 54.7^{\prime \prime} \mathrm{W}\right)$. Adults were transferred to leaflets of $A$. merrillii placed (upside down) onto a piece of foam map moisten daily with distilled water. Mites were weekly transferred to new leaflets. The stock colony was maintained in Entomology Laboratory of Embrapa Roraima at uncontrolled environmental conditions (ca. $26{ }^{\circ} \mathrm{C}, 60 \% \mathrm{RH}$ and natural photophase (ca. 12:12 h L: D). Twenty-one day before of the study, 100 adult females were transferred to a new A. merrillii leaflet and removed $24 \mathrm{~h}$ later, leaving only the eggs they laid. This new generation was reared to adulthood to be used in the determination of the instantaneous rate of increase $\left(r_{i}\right)$.

\subsection{Instantaneous Rate of Increase}

The experiment was conducted in a screenhouse at Embrapa Roraima. It was conducted under a randomized block design, with five blocks and 19 plant species as treatments, each experimental unit corresponding to a plant. Three recently molted adult females of $R$. indica were transferred to a rectangle of $1.5 \times 3.0 \mathrm{~cm}$ delineated with entomological glue onto the lower surface of a randomly selected leaf or leaflet (according to plant species) of each third (basal, median and apical) of each seedling. The number of mites in each developmental stage in each rectangle was counted 7, 14, 21 and 28 days later. The instantaneous rate of increase $\left(r_{i}\right)$ of $R$. indica on each plant species was estimated using the following equation proposed by Hall (1964):

$$
r_{i}=\ln \left(\mathrm{n}_{\mathrm{f}} / \mathrm{n}_{\mathrm{o}}\right) / \Delta_{\mathrm{t}}
$$

Where, $\mathrm{n}_{\mathrm{f}}$ is the final number of mites, $\mathrm{n}_{\mathrm{o}}$ is the initial number of mites, and $\Delta_{\mathrm{t}}$ is the elapsed time. Mean values were calculated as follows: 


$$
r_{i}=\left(r_{i 7}+r_{i 14}+r_{i 21}+r_{i 28}\right) / 4
$$

Where, $r_{i 7}, r_{i 14}, r_{i 21}$ and $r_{i 28}$ are respectively the instantaneous rate of increase for each species 7, 14, 21 and 28 days after mite confinement. Using a modification of the criterium proposed by Stark, Tanigoshi, Bounfour and Antonelli (1997) and Walthall and Stark (1997), the suitability of plant species as host estimated by the determined values of $r_{i}$. The plant was classified as "primary or potential primary host" if $r_{i}>0.05$, as "potential secondary host" if $r_{i}=0.05-0.00$, and as "non-host" if $r_{i}<0.00$.

\subsection{Biological Parameters}

Developmental time, oviposition and daily survivorship rates of $R$. indica were determined on the following plant species on which $r_{i}$ was positive: A. jauari, A. merrillii, B. simplicifrons, C. nucifera, H. psittacorum, M. flexuosa, Musa $\times$ paradisiaca (Prata variety), O. bacaba, O. bataua, P. dactylifera and S. exorrhiza and on two native species on which $r_{i}$ was negative (E. precatoria and E. oleracea); the latter two plants were included because of their economic and ecological importance in the Amazon region. A completely randomized design was adopted, using five seedlings of A. merrillii, E. precatoria, E. oleraceae, M. flexuosa, O. bacaba, O. bataua, P. dactylifera and Musa $\times$ paradisiaca and 8-10 seedlings of A. jauari, B. simplicifrons, C. nucifera, S. exorrhiza and $H$. psittacorum (numbers varying according to the architecture/structure of each plant).

The study was initiated with recently laid eggs. For such, three $R$. indica adult females were transferred from the stock colony to rectangles $(2.0 \times 3.0 \mathrm{~cm})$ delimited with entomological glue on the undersurface of undetached leaflets (one on each of seven leaflets of composite leaves) or leaves (seven rectangles on a single non-composite leaf) at taken from the median stratum of the plant canopy. Twenty-four hours later, the females and part of the eggs laid were removed, leaving one to five eggs per rectangle. The units were examined once a day for counting the number of mites in each stage. Newly emerged females were transferred to new similar experimental units, adding an adult male taken from the stock colony to each unit. Dead males were replaced by new ones until the female died. Sex ratio was estimated based on offspring obtained in the first 10 days of oviposition (Schulten, 1985).

All evaluations for the determination of $r_{i}$ and for the study of the biology of $R$. indica were carried out using $30 \times$ or $60 \times$ hand lens (LED HG498). The environmental conditions were recorded every 10 minutes using a Hobo Data Loggers ${ }^{\circledR}$.

\subsection{Statistical Analysis}

Values of $r_{i}$, viability of immature forms, developmental time, oviposition period, sex ratio, longevity and daily oviposition rates were subjected to an analysis of variance (PROC GML), using the statistical package SAS version 9.0 (SAS Institute, 2003, 2008), after testing the data for normality and homoscedasticity (Kolmogorov and Bartlett tests, respectively). Data that could not be normalized were subjected to Kruskal-Wallis non-parametric test (Proc NPAR1WAY), SAS version 9.0 (SAS Institute, 2003, 2008). Fertility life table parameters [net reproductive rate $(R o)$, generation time $(T)$, and intrinsic rate of increase $\left(r_{m}\right)$ ] were estimated using the Jackknife procedure, as described by Maia, Luiz and Campanhola (2000), using SAS/Enterprise Guide 4.3 (SAS Institute, 2003, 2008). Pearson correlation between $r_{i}$ and $r_{m}$ was performed (SAS/Enterprise Guide 4.3, SAS Institute, 2003, 2008).

\section{Results}

\subsection{The Instantaneous Rate of Increase}

Significant differences in $r_{i}$ values were observed seven days $\left(\chi^{2}=197.18 ; \mathrm{df}_{18,250} ; \mathrm{P}<0.0001\right), 14$ days $\left(\chi^{2}=\right.$ $\left.130.71 ; \mathrm{df}_{17,170} ; \mathrm{P}<0.0001\right), 21$ days $\left(\chi^{2}=60.47 ; \mathrm{df}_{13,117} ; \mathrm{P}<0.0001\right)$ and 28 days $\left(\chi^{2}=62.37 ; \mathrm{df}_{9,104} ; \mathrm{P}<\right.$ 0.0001)] after mite confinement (Table 1). Values higher than 0.05 were observed on A. jauari, A. merrillii, B. simplicifrons, C. nucifera, M. flexuosa, P. dactylifera, S. exorrhiza and H. psittacorum; almost invariably, these values reduced along the experiment. Values between 0.05 and 0.00 were observed on B. maraja, O. bacaba, O. bataua and Musa × paradisiaca. Negative values were observed on A. aculeatum, A. maripa, A. rosea, B. gasipaes, E. guineensis, E. oleraceae and E. precatoria. 
Table 1. Estimation of instantaneous rate of increase $\left(r_{i}\right.$; Mean \pm SE) of Raoiella indica on different hosts. Boa Vista, Roraima State, Brazil. $\mathrm{T}=29 \pm 4,03{ }^{\circ} \mathrm{C}, \mathrm{RH}=78 \pm 13,32 \%$, natural light: darkness (ca. 12:12 h)

\begin{tabular}{|c|c|c|c|c|c|c|c|}
\hline \multirow{2}{*}{ Species } & \multirow{2}{*}{ Family } & \multicolumn{6}{|c|}{ Days from infestation date } \\
\hline & & 7 & 14 & 21 & 28 & Overall Mean & Status $^{\mathrm{a}}$ \\
\hline \multicolumn{8}{|l|}{ EXOTICS } \\
\hline Adonidia merrillii & Arecaceae & $0.34 \pm 0.01 \mathrm{a}^{\mathrm{a}}$ & $0.18 \pm 0.01 \mathrm{a}$ & $0.11 \pm 0.01 \mathrm{a}$ & $0.11 \pm 0.01 \mathrm{a}$ & $0.19 \pm 0.01$ & Host \\
\hline Cocos nucifera & “ & $0.26 \pm 0.01 \mathrm{~b}$ & $0.16 \pm 0.01 \mathrm{ab}$ & $0.11 \pm 0.01 \mathrm{ab}$ & $0.08 \pm 0.01 \mathrm{~b}$ & $0.15 \pm 0.01$ & Host \\
\hline Elaeis guineensis & “ & $-0.01 \pm 0.01 \mathrm{ef}$ & Extinct & & & $-0.01 \pm 0.02$ & Non-host \\
\hline Phoenix dactylifera & “ & $0.16 \pm 0.02 \mathrm{c}$ & $0.08 \pm 0.02$ ef & $0.04 \pm 0.01 \mathrm{def}$ & $0.04 \pm 0.01 \mathrm{c}$ & $0.08 \pm 0.01$ & Host \\
\hline Alpinia rosea & Zingiberaceae & $0.01 \pm 0.02 \mathrm{e}$ & $-0.03 \pm 0.01 \mathrm{~g}$ & $-0.05 \mathrm{f}$ & Extinct & $-0.02 \pm 0.01$ & Non-host \\
\hline Musa $\times$ paradisiaca & Musaceae & $-0.01 \pm 0.04 \mathrm{ef}$ & $0.02 \pm 0.04 \mathrm{fg}$ & $0.03 \pm 0.08$ cdfe & $0.06 \mathrm{abcdb}$ & $0.02 \pm 0.03$ & Secondary host \\
\hline \multicolumn{8}{|l|}{ NATIVES } \\
\hline Astrocaryum aculeatum & Arecaceae & $0.00 \pm 0.02 \mathrm{e}$ & $-0.05 \pm 0.01 \mathrm{~g}$ & Extinct & & $-0.02 \pm 0.01$ & Non-host \\
\hline Astrocaryum jauari & “ & $0.23 \pm 0.01 \mathrm{~b}$ & $0.12 \pm 0.01 \mathrm{~cd}$ & $0.06 \pm 0.01 \mathrm{~d}$ & $0.03 \pm 0.01 \mathrm{c}$ & $0.11 \pm 0.01$ & Host \\
\hline Attalea maripa & “ & $-0.06 \pm 0.02$ ef & $-0.06 \pm 0.01 \mathrm{~g}$ & $-0.05 \pm 0.01 \mathrm{f}$ & Extinct & $-0.05 \pm 0.02$ & Non-host \\
\hline Bactris gasipaes & “ & $-0.04 \pm 0.02$ ef & $-0.04 \pm 0.02 \mathrm{~g}$ & Extinct & & $-0.04 \pm 0.0$ & Non-host \\
\hline Bactris maraja & “ & $0.07 \pm 0.02 \mathrm{~d}$ & $0.00 \pm 0.01 \mathrm{~g}$ & $0.00 \mathrm{def}$ & Extinct & $0.02 \pm 0.01$ & Secondary host \\
\hline Bactris simplicifrons & “ & $0.22 \pm 0.01 \mathrm{~b}$ & $0.13 \pm 0.01 \mathrm{bc}$ & $0.09 \pm 0.01$ & $0.07 \pm 0.01 \mathrm{~b}$ & $0.13 \pm 0.01$ & Host \\
\hline Euterpe precatoria & “ & $-0.06 \pm 0.02$ ef & $-0.05 \pm 0.03 \mathrm{~g}$ & Extinct & & $-0.06 \pm 0.02$ & Non-host \\
\hline Euterpe oleracea & “ & $0.02 \pm 0.02 \mathrm{de}$ & $-0.04 \pm 0.02 \mathrm{~g}$ & Extinct & & $-0.01 \pm 0.01$ & Non-host \\
\hline Mauritia flexuosa & “ & $0.25 \pm 0.01 \mathrm{~b}$ & $0.13 \pm 0.01 \mathrm{c}$ & $0.06 \pm 0.01$ & $0.02 \pm 0.01 \mathrm{~cd}$ & $0.12 \pm 0.01$ & Host \\
\hline Oenocarpus bacaba & “ & $0.06 \pm 0.03 \mathrm{de}$ & $0.04 \pm 0.02$ ef & $0.06 \pm 0.01$ & $0.05 \pm 0.01 \mathrm{c}$ & $0.05 \pm 0.01$ & Secondary Host \\
\hline Oenocarpus bataua & “ & $0.00 \pm 0.04 \mathrm{e}$ & $0.00 \pm 0.04 \mathrm{~g}$ & $0.06 \pm 0.02$ & Extinct & $0.02 \pm 0.02$ & Secondary Host \\
\hline Socratea exorrhiza & “ & $0.21 \pm 0.02 \mathrm{bc}$ & $0.09 \pm 0.02 \mathrm{de}$ & $0.04 \pm 0.01$ & $0.02 \pm 0.01 \mathrm{~cd}$ & $0.09 \pm 0.01$ & Host \\
\hline Heliconia psittacorum & Heliconiaceae & $0.16 \pm 0.02 \mathrm{c}$ & $0.09 \pm 0.01 \mathrm{ef}$ & $0.03 \pm 0.01$ & $0.01 \pm 0.01 \mathrm{~d}$ & $0.07 \pm 0.01$ & Host \\
\hline
\end{tabular}

Note. ${ }^{\text {a}}$ Potential primary hosts (= hosts): overall $r_{i}>0.05$; Potential secondary host: $0.0 \leq$ overall $r_{i} \leq 0.05$; Non-hosts: $r i<0$. Within a column, means followed by the same letter are not significantly different (Kruskal-Wallis test: $\mathrm{p}>0.05$ ).

\subsection{Biological Parameters}

RPM completed development on all evaluated plant species (Table 2). However, the few females reaching adulthood on E. oleracea and E. precatoria did not oviposit. Mean developmental time ranged from 14.7 days on C. nucifera to 21.4 days on Musa $\times$ paradisiaca, showing a significant influence of the host $\left(\chi^{2}=235.6 ; \mathrm{df}_{12,303}\right.$; $\mathrm{P}<0.0001)$. The same was observed for viability $\left(\chi^{2}=140.1 ; \mathrm{df}_{12,399} ; \mathrm{P}<0.0001\right)$, which ranged from $95.4 \%$ on C. nucifera to $2.3 \%$ on E. oleraceae (Table 2).

Table 2. Immature developmental time (days) and viability (\%) (Mean $\pm \mathrm{SE}$ ) of Raoiella indica on different hosts. Boa Vista, Roraima state, Brazil. $\mathrm{T}=30 \pm 4,61^{\circ} \mathrm{C}, \mathrm{RH}=69 \pm 15,04 \%$, natural light: darkness (ca. 12:12 h)

\begin{tabular}{llll}
\hline Hosts & $\mathrm{N}^{\mathrm{a}}$ & Developmental time & Viability \\
\hline Adonidia merrillii & 83 & $15.0 \pm 0.13 \mathrm{~g}$ & $85.3 \pm 2.73 \mathrm{ab}$ \\
Astrocaryum jauari & 75 & $17.8 \pm 0.14 \mathrm{c}$ & $69.4 \pm 4.48 \mathrm{bcd}$ \\
Bactris simplicifrons & 84 & $16.0 \pm 0.11 \mathrm{ef}$ & $66.8 \pm 4.87 \mathrm{bcd}$ \\
Cocos nucifera & 63 & $14.7 \pm 0.13 \mathrm{~g}$ & $95.4 \pm 1.55 \mathrm{a}$ \\
Euterpe oleracea & 64 & $19.0 \pm 0.0 \mathrm{abc}$ & $2.3 \pm 1.12 \mathrm{f}$ \\
Euterpe precatoria & 30 & $15.4 \pm 0.07 \mathrm{f}$ & $24.1 \pm 7.28 \mathrm{e}$ \\
Heliconia psittacorum & 70 & $18.9 \pm 0.15 \mathrm{~b}$ & $88.9 \pm 3.02 \mathrm{a}$ \\
Mauritia flexuosa & 74 & $17.0 \pm 0.18 \mathrm{~cd}$ & $55.0 \pm 5.52 \mathrm{~cd}$ \\
Musa $\times$ paradisiaca & 152 & $21.4 \pm 0.23 \mathrm{a}$ & $69.6 \pm 3.48 \mathrm{bc}$ \\
Oenocarpus bacaba & 47 & $17.3 \pm 0.16 \mathrm{~cd}$ & $39.9 \pm 7.28 \mathrm{de}$ \\
Oenocarpus bataua & 43 & $20.3 \pm 0.30 \mathrm{ab}$ & $25.8 \pm 6.06 \mathrm{e}$ \\
Phoenix dactylifera & 75 & $15.9 \pm 0.11 \mathrm{f}$ & $93.3 \pm 1.73 \mathrm{a}$ \\
Socratea exorrhiza & 67 & $16.3 \pm 0.14 \mathrm{e}$ & $81.1 \pm 4.51 \mathrm{ab}$ \\
\hline
\end{tabular}

Note. ${ }^{a}$ Number of mite specimens. Means within a column followed by the same letter are not significantly different (Kruskal-Wallis test: $\mathrm{p}>0.05$ ). 
Longevity was longer (Table 3) on P. dactylifera (47.3 days) and shorter on M. flexuosa, Oenocarpus spp. and A. merrillii (19.2-21.7 days), while oviposition was longer on P. dactylifera (34.4 days) and shorter on M. flexuosa and Oenocarpus spp. (9.6-12.7 days) $\left(\chi^{2}=164.9 ; \mathrm{df}_{10,434} ; \mathrm{P}<0.0001\right)$, and fecundity was higher on $P$. dactylifera (25.0 eggs) and lower on O. bataua (5.2 ovos) and Musa $\times$ paradisiaca (Prata variety) (4.2 eggs) ( $\chi^{2}$ $=234.5 ; \mathrm{df}_{10,460} ; \mathrm{P}<0.0001$ ). However, sex ratio (proportion of females) ranged from 0.57 to 0.72 , with no significant differences between plant species $\left(\chi^{2}=17.18 ; \mathrm{df}_{10,99} ; \mathrm{P}<0.0705\right)$ (Table 3$)$.

Net reproductive rate $\left(\mathrm{R}_{0}\right)$ and intrinsic rate of increase $\left(r_{m}\right)$ were also affected by plant species $(\mathrm{p}<0.05)$ (Table 4). The highest $\mathrm{R}_{0}$ was on P. dactylifera (14.7) and the lowest on $O$. bataua (0.9), while the highest $r_{m}$ was on $A$. merrilliii, C. nucifera and S. exorrrhiza (0.094-0.103) and the lowest on $O$. bataua (-0.002). Mean generation time (T) was also affected by host $(\mathrm{p}<0.05)$, being shorter on A. merrillii (20.3 days) and longer on $O$. bataua (36.1 days) (Table 4). A significant and positive correlation was observed between $r_{i}$ and $r_{m}(\mathrm{n}=33 ; r=0.62 ; \mathrm{p}<$ $0.0001)$.

\section{Discussion}

Estimated instantaneous rates of increase $\left(r_{i}\right)$ showed that RPM can colonize several of the evaluated plant species, both native and introduced, suggesting the ability to maintain itself in the Amazon region on wild and cultivated plants. Obviously this does not mean that the mite actually threatens those plants in nature, given that prevailing climatic factors as well as natural enemies and other biotic factors may restrain RPM from reaching high populations.

The trend for the reduction of $r_{i}$ values along the duration of the experiment in several of the evaluated plant species might be spurious, being conceivably due to the progressive reduction of the suitability of the plant substrate with the increasing mite population in a restricted space (Reddall, Sadras, Wilson, \& Gregg, 2004), which could lead to increasing intraspecific competition for food and space (Elkinton, 2009). Partial support to this hypothesis is the fact that for plants with lower $r_{i}$ value, this parameter remained about constant (ex. $O$. bataua) or tended to increase (on M. paradisiaca and $O$. bacaba) during the experiment. In about half of the plants tested, RPM population decreased through time (A. aculeatum, A. maripa, A. rosea, B. gasipae, B. maraja, E. guineensis, E. oleraceae, E. precatoria and $O$. bataua), leading to the conclusion that these species are not threatened by the expanding geographic distribution of RPM in Brazil.

Table 3. Longevity (days), oviposition period (days), fecundity (eggs/female) and sex ratio (mean $\pm \mathrm{SE}$ ) of Raoiella indica on different plant species. Boa Vista, Roraima, Brazil. $\mathrm{T}=30 \pm 4,61^{\circ} \mathrm{C}, \mathrm{RH}=69 \pm 15,04 \%$, natural light: darkness (ca. 12:12 h).

\begin{tabular}{llllll}
\hline Hosts & $\mathrm{N}^{\mathrm{a}}$ & Longevity & Oviposition period & Fecundity & Sex ratio \\
\hline Adonidia merrillii & 44 & $20.1 \pm 0.65 \mathrm{~cd}$ & $13.8 \pm 0.51 \mathrm{fg}$ & $15.8 \pm 0.68 \mathrm{~b}$ & $0.60 \pm 0.01 \mathrm{a}$ \\
Astrocaryum jauari & 46 & $28.0 \pm 1.46 \mathrm{~b}$ & $16.8 \pm 1.14 \mathrm{cde}$ & $10.8 \pm 0.70 \mathrm{~cd}$ & $0.63 \pm 0.02 \mathrm{a}$ \\
Bactris simplicifrons & 47 & $30.9 \pm 1.39 \mathrm{~b}$ & $20.2 \pm 1.34 \mathrm{~b}$ & $12.2 \pm 1.01 \mathrm{c}$ & $0.58 \pm 0.02 \mathrm{a}$ \\
Cocos nucifera & 38 & $27.1 \pm 0.97 \mathrm{~b}$ & $18.6 \pm 0.98 \mathrm{bc}$ & $15.4 \pm 1.08 \mathrm{~b}$ & $0.63 \pm 0.08 \mathrm{a}$ \\
Heliconia psittacorum & 40 & $26.9 \pm 1.40 \mathrm{~b}$ & $15.9 \pm 0.97 \mathrm{def}$ & $10.7 \pm 0.67 \mathrm{~cd}$ & $0.65 \pm 0.02 \mathrm{a}$ \\
Mauritia flexuosa & 55 & $19.2 \pm 0.94 \mathrm{~d}$ & $11.0 \pm 0.77 \mathrm{~h}$ & $10.2 \pm 0.83 \mathrm{~d}$ & $0.62 \pm 0.03 \mathrm{a}$ \\
Musa $\times$ paradisiaca & 58 & $23.1 \pm 1.65 \mathrm{c}$ & $12.8 \pm 1.19 \mathrm{ef}$ & $4.2 \pm 0.54 \mathrm{e}$ & $0.72 \pm 0.02 \mathrm{a}$ \\
Oenocarpus bacaba & 34 & $21.7 \pm 1.34 \mathrm{~cd}$ & $12.7 \pm 1.03 \mathrm{gh}$ & $10.8 \pm 1.07 \mathrm{~d}$ & $0.57 \pm 0.01 \mathrm{a}$ \\
Oenocarpus bataua & 27 & $20.4 \pm 1.73 \mathrm{~cd}$ & $9.6 \pm 1.31 \mathrm{~h}$ & $5.2 \pm 0.68 \mathrm{e}$ & $0.61 \pm 0.05 \mathrm{a}$ \\
Phoenix dactylifera & 51 & $47.3 \pm 1.79 \mathrm{a}$ & $34.4 \pm 1.45 \mathrm{a}$ & $25.0 \pm 1.04 \mathrm{a}$ & $0.63 \pm 0.01 \mathrm{a}$ \\
Socratea exorrhiza & 30 & $26.6 \pm 1.39 \mathrm{~b}$ & $17.3 \pm 1.00 \mathrm{bcd}$ & $17.6 \pm 1.25 \mathrm{~b}$ & $0.60 \pm 0.02 \mathrm{a}$ \\
\hline
\end{tabular}

Note. ${ }^{a}$ Number of mite specimens. Within a column, means followed by the same letter are not significantly different (Kruskal-Wallis test: $\mathrm{p}>0.05$ ). 
Table 4. Net reproductive rate $\left(R_{0}\right)$, intrinsic rate of increase $\left(r_{m}\right)$ and mean generation time $(T)(\mathrm{mean} \pm \mathrm{CI})$ of Raoiella indica on different plant species. Boa Vista, Roraima, Brazil. $\mathrm{T}=30 \pm 4,61{ }^{\circ} \mathrm{C}, \mathrm{RH}=69 \pm 15,04 \%$, natural light: darkness (ca. 12:12 h)

\begin{tabular}{lllll}
\hline Hosts & $\mathrm{N}^{\mathrm{a}}$ & $\mathrm{R}_{\mathrm{o}}\left[(+)(+)^{-1}\right]$ & $r_{m}\left[(+)(+)^{-1}(\mathrm{day})^{-1}\right]$ & $\mathrm{T}($ days $)$ \\
\hline Adonidia merrillii & 44 & $8.1(7.4-8.8) \mathrm{b}$ & $0.103(0.099-0.107) \mathrm{a}$ & $20.3(19.9-20.7) \mathrm{a}$ \\
Astrocaryum jauari & 46 & $4.7(4.1-5.3) \mathrm{c}$ & $0.061(0.056-0.066) \mathrm{c}$ & $25.3(24.3-26.2) \mathrm{b}$ \\
Bactris simplicifrons & 47 & $4.7(3.9-5.5) \mathrm{cd}$ & $0.065(0.058-0.071) \mathrm{c}$ & $24.0(23.1-25.0) \mathrm{b}$ \\
Cocos nucifera & 38 & $9.2(7.9-10.5) \mathrm{b}$ & $0.097(0.092-0.103) \mathrm{ab}$ & $22.9(22.0-23.7) \mathrm{b}$ \\
Heliconia psittacorum & 40 & $6.2(5.4-7.0) \mathrm{c}$ & $0.065(0.060-0.069) \mathrm{c}$ & $28.1(27.3-28.9) \mathrm{c}$ \\
Mauritia flexuosa & 55 & $3.5(2.9-4.2) \mathrm{d}$ & $0.058(0.050-0.065) \mathrm{c}$ & $22.1(21.3-22.9) \mathrm{b}$ \\
Musa $\times$ paradisiaca & 49 & $2.1(1.6-2.6) \mathrm{e}$ & $0.028(0.018-0.038) \mathrm{d}$ & $26.9(26.0-27.8) \mathrm{c}$ \\
Oenocarpus bacaba & 34 & $2.0(1.5-2.5) \mathrm{e}$ & $0.030(0.020-0.040) \mathrm{d}$ & $23.7(22.7-30.8) \mathrm{bcd}$ \\
Oenocarpus bataua & 27 & $0.9(0.7-1.2) \mathrm{f}$ & $-0.002(-0.009-0.006) \mathrm{e}$ & $36.1(33.1-39.2) \mathrm{e}$ \\
Phoenix dactylifera & 51 & $14.7(13.5-15.9) \mathrm{a}$ & $0.090(0.087-0.093) \mathrm{b}$ & $30.0(29.2-30.9) \mathrm{d}$ \\
Socratea exorrhiza & 30 & $9.0(7.7-0.3) \mathrm{b}$ & $0.094(0.087-0.100) \mathrm{ab}$ & $23.4(22.6-24.2) \mathrm{b}$ \\
\hline
\end{tabular}

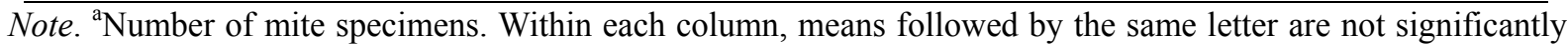
different (T test: $\mathrm{P}>0.05)$.

The reasons for those different levels of susceptibility are not known, but could be due to plant defense factors (Painter, 1958; Price, 1986; Stout, 2013). According to Isman and Grieneisen (2014) plants developed complex chemical arsenals (terpenoids, flavonoids, tannins and alkaloids) with phytochemical activities that can act as deterrents to feeding or oviposition, reducing the performance of herbivores (Novaes, Molinillo, Varela, \& Macías, 2013; Pavela, 2010; Rattan, 2010). Variability of leaf structures can also provide mechanical or physiological characteristics that can interfere with the ability of a particular mite species to use a plant as host. In palm trees, such structures can be scales of the abaxial leaf surface, presence of epicuticular wax, as well as the presence of trichomes in different densities (Beard et al., 2012; Horn, Fisher, Tomlinson, Lewis, \& Laubengayer, 2009; Valverde, Fornoni, \& Núñez-Farfán, 2001). Another important aspect concerning RPM refers to the characteristics of the stomata. Beard et al. (2012) mentioned that this mite feeds by piercing cells inside the stomata. These authors showed that feeding by RPM is greatly influenced by the behavior of the stomata, and that Raoiella species cannot feed on hosts with closed or covered stomatal openings.

Results of the present study suggest that native Brazilian plant species (A. jauari, B. simplicifrons, M. flexuosa, $O$. bacaba, S. exorrhiza and H. psittacorum) could be at risk with the expansion of the distribution of RPM, given that the values of $r_{i}$ for those species are similar to the values obtained for well known exotic hosts, as $A$. merrillii and C. nucifera (Carrillo et al., 2012; Vásquez et al., 2015). However, quite different life table parameters were found in this and previous studies. The value of $r_{m}$ was much higher on $A$. merrillii in this study than reported by Vásquez et al. (2015) at a slightly lower temperature $\left(29{ }^{\circ} \mathrm{C} ; r_{m}=0.042\right.$, against 0.1 in this study). This difference could be due to the fact that in the present study the rearing units were established on undetached leaves, which would supposedly be more adequate for not promoting the closure of the stomata (Beard et al., 2012). However, quite the opposite was found on $C$. nucifera, for which those authors reported $r_{m}$ of 0.166 (against 0.097 in this study). Thus, detachment of leaves may disturb RPM performance, but obviously other factors might have important bearing as well. In any case, in both studies C. nucifera and A. merrillii were the hosts on which $R$. indica best performed.

The intrinsic rate of natural increase $\left(r_{m}\right)$ value is used for revealing the impact of a parameter $(e . g$. temperature, host plant) on the demographic potential of an organism (Birch, 1948; Dent, 1997). Under optimum conditions, $r_{m}$ will attain its maximum possible value (Dent, 1997). Meanwhile, the instantaneous rate of increase $\left(r_{i}\right)$ measures the ability of a population to increase over time (Hall, 1964). Walthall and Stark (1997) considered that $r_{i}$ provides information on short-term and real populations are evaluated in shorter time and at less expense than the traditional life table method. These authors obtained high correlation between these two demographic parameters $\left(r^{2}=0.91, \mathrm{n}=21, p<0.01\right)$ for populations of pea aphid, Acyrthosiphon pisum (Harris) (Hemiptera: Aphididae), used as the model species and exposed to the nicotinergic insecticide imidacloprid, as xenobiotic sprayed on potted broad bean, Vicia faba L. (variety Banner), suggesting that $r_{i}$ can be used as a substitute measure for $r_{m}$. The $r_{i}$ has been used in the assessment of xenobiotics, especially concentration-response laboratory bioassays (Stark et al., 1997; Tuelher, Venzon, Guedes, \& Pallini, 2014; Walthall \& Stark, 1997). 
All native plant species classified as potential primary hosts of RPM in this study (A. jauari, B. simplicifrons, $M$. flexuosa, O. bacaba, S. exorrhiza and H. psittacorum) have great relevance to indigenous people, for extractivism and/ or maintenance of wildlife of the Amazon biome, providing important elements as food, construction items, shelter, medicine, handcraft raw material, fibers etc. (Mesa \& Galeano, 2013; Paniagua-Zambrana et al., 2007; Sosnowska \& Balslev, 2009). Some of the palm species, as S. exorrhiza, are among the 20 most abundant plants in the Amazon biome (Steege et al., 2013). Many of these palms are found in conservation areas, where mite control is difficult to apply. The conceivable significant role of prevailing natural enemies on RPM population on those plants remains to be demonstrated. These could eventually prevent RPM from causing significant damage to those hosts. The study of these and related aspects is warranted.

In conclusion, the red palm mite has the potential to cause severe damage to plants native to the Brazilian Amazon. Eight species were concluded in this study to be potential primary hosts, of which five are native to that biome, namely the Arecaceae A. jauari, B. simplicifrons, M. flexuosa and S. exorrhiza, and the Heliconiaceae $H$. psittacorum. This seems relevant, because all of these species are important for extractivism by indigenous people and/or for maintenance of wildlife.

\section{References}

Beard, J. J., Ochoa, R., Bauchan, G. R., Welbourn, W. C., Pooley, C., \& Dowling, A. P. G. (2012). External mouthpart morphology in the Tenuipalpidae (Tetranychoidea): Raoiella a case study. Experimental and Applied Acarology, 57, 227-255. https://doi.org/10.1007/s10493-012-9540-2

Birch, L. C. (1948). The intrinsic rate of natural increase of an insect population. Journal of Animal Ecology, 17, 15-26. https://doi.org/10.2307/1605

Carrillo, D., Amalin, D., Hosein, F., Roda, A., Duncan, R. E., \& Peña, E. J. (2012). Host plant range of Raoiella indica (Acari: Tenuipalpidae) in areas of invasion of the New World. Experimental and Applied Acarology, 57, 271-289. https://doi.org/10.1007/s10493-011-9487-8

Carrillo, D., Navia, D., Ferragut, F., \& Peña, J. E. (2011). First report of Raoiella indica (Acari: Tenuipalpidae) in Colombia. Florida Entomologist, 94, 370-371. https://doi.org/10.1653/024.094.0241

Dent, D. R. (1997). Quantifying insect populations: Estimates and parameters. In D. R. Dent, \& M. P. Walton (Eds.), Methods in ecological and agricultural entomology (pp. 57-110). New York, NY: CAB International.

Dowling, A. P. G., Ochoa, R., Beard, J. J., Welrn, W. C., \& Ueckermann, E. A. (2012). Phylogenetic investigation of the genus Raoiella (Prostigmata: Tenuipalpidae): Diversity, distribution, and world invasions. Experimental and Applied Acarology, 57, 257-269. https://doi.org/10.1007/s10493-011-9483-z

Elkinton, J. S. (2009). Population ecology. In V. H. Resh, \& R. T. Cardé (Eds.), Encyclopedia of insects (pp. 826-837). Amsterdam: Elsevier. https://doi.org/10.1016/B978-0-12-374144-8.00218-6

Empresa Brasileira de Pesquisa Agropecuária. (December 15, 2015). Fique atento ao ácaro-vermelho-das-palmeiras. Embrapa Tabuleiros Costeiros, Aracajú. Retrieved from https://www. embrapa.br/en/busca-de-noticias/-/noticia/8356528/fique-atento-ao-acaro-vermelho-das-palmeiras

Flechtmann, C. H. W., \& Etienne, J. (2004). The red palm mite, Raoiella indica Hirst, a threat to palms in the Americas (Acari: Prostigmata: Tenuipalpidae). Systematic and Applied Acarology, 9, 109-110. https://doi.org/10.11158/saa.9.1.16

Gondim Jr., M. G. C., Castro, T. M. M. G., Marsaro, A. L., Navia, D., Melo, J. W. S., Demite, P. R., \& Moraes, G. J. (2012). Can the red palm mite threaten the Amazon vegetation? Systematics and Biodiversity, 10, 527-535. https://doi.org/10.1080/14772000.2012.752415

Hall, D. J. (1964). An experimental approach to the dynamics of a natural population of Daphnia galeata mendotae. Ecology, 45, 94-112. https://doi.org/10.2307/1937111

Hirst, S. (1924). On some new species of red spider. Annual and Magazine of Natural History, 14, 522-527. https://doi.org/10.1080/00222932408633151

Horn, W. J., Fisher, J. B., Tomlinson, P. B., Lewis, C. E., \& Laubengayer, K. (2009). Evolution of lamina anatomy in the palm family (Arecaceae). American Journal of Botany, 96, 1462-1486. https://doi.org/10.3732/ajb.0800396

Isman, M. B., \& Grieneisen, M. I. (2014). Botanical insecticide research: many publications, limited useful data. Trens in Plant Science, 19, 140-145. https://doi.org/10.1016/j.tplants.2013.11.005 
Kane, E. C., Ochoa, R., Mathurin, G., Erbe, E. F., \& Beard, J. J. (2012). Raoiella indica (Acari: Tenuipalpidae): an exploding mite pest in the neotropics. Experimental Applied Acarology, 57, 215-225. https://doi.org/ $10.1007 / \mathrm{s} 10493-012-9541-1$

Maia, A. H. N., Luiz, A. J. B., \& Campanhola, C. (2000). Statistical inference on associated fertility life table parameters using Jackknife technique: Computational aspects. Journal Economic Entomology, 93, 511-518. https://doi.org/10.1603/0022-0493-93.2.511

Mesa, L., \& Galeano, G. (2013). Uso y manejo de las palmas (Arecaceae) por los Piapoco del Norte de la Amazonia colombiana. Acta Botánica Venezuelica, 36, 15-38.

Navia, D., Marsaro Jr. A. L., Silva F. R., Gondim Jr., M. G. C., \& Moraes, G. J. (2011). First report of the red palm mite, Raoiella indica Hirst (Acari: Tenuipalpidae), in Brazil. Neotropical Entomology, 40, 409-411. https://doi.org/10.1590/S1519-566X2011000300018

Navia, D., Morais, E. G. F., Mendoça, R. S., \& Gondim Jr., M. G. C. (2015). Ácaro vermelho-das-palmeiras, Raoiella indica Hirst. In E. F. Vilela, \& R. A. Zucchi (Eds.), Pragas introduzidas no Brasil: Insetos e ácaros (pp. 418-452). Piracicaba, SP: ESALQ/USP.

North American Plant Protection Organization. (November 20, 2009). Detection of the red palm mite (Raoiella indica) in Cancun and Isla Mujeres, Quintana Roo, Mexico. Retrieved from http://www.pestalert.org/opr Detail.cfm?oprID $=406$

Novaes, P., Molinillo, J. M. G., Varela, R. M., \& Macías, F. A. (2013). Ecological phytochemistry of Cerrado (Brazilian savanna) plants. Phytochemistry Reviews, 12, 839-855. https://doi.org/10.1007/s11101-0139315-3

Oliveira, D. C., Prado, E. P., Moraes, G. J., Morais, E. G. F., Chagas, E. A., Gondim Jr., M. G. C., \& Navia, D. (2016). First report of Raoiella indica (Acari: Tenuipalpidae) in southeastern Brazil. Florida Entomologist, 99, 123-125. https://doi.org/10.1653/024.099.0124

Painter, R. H. (1958). Resistance of plants to insects. Annual Review of Entomology, 3, $267-290$. https://doi.org/10.1146/annurev.en.03.010158.001411

Paniagua-Zambrana, N. Y., Byg, A., Svenning, J.-C., Moraes, M., Grandez, C., \& Balslev, H. (2007). Diversity of palm uses in the western Amazon. Biodiversity and Conservation, 16, 2771-2787. https://doi.org/10.1007/s10531-007-9218-y

Pavela, R. (2011). Natural products as allelochemicals in pest management. In N. K. Dubey (Ed.), Natural products in plant pest management (pp. 134-148). London, England: CABI.

Peña, J. E., Bruin, J., \& Sabelis, M. W. (2012). Biology and control of the red palm mite, Raoiella indica: an introduction. Experimental Applied Acarology, 57, 211-213. https://doi.org/10.1007/s10493-012-9569-2

Price, P. W. (1986). Ecological aspects of host plant resistance and biological control: interations among three trophic levels. In D. J. Boethel, \& R. D. Eikenbary (Eds.), Interations of plant resistance and parasitoids and predators of insects (pp. 11-36). New York, NY: Jonh Wiley.

Rattan, R. S. (2010). Mechanism of action of insecticidal secondary metabolites of plant origin. Crop Protection, 29, 913-920. https://doi.org/10.1016/j.cropro.2010.05.008

Reddall, A., Sadras, V. O., Wilson, L. J., \& Gregg, P. C. (2004). Physiological responses of cotton to two-spotted spider mite damage. Crop Science, 44, 835-846. https://doi.org/10.2135/cropsci2004.0835

Rodrigues, J. C. V., \& Antony, L. M. K. (2011). First report of Raoiella indica (Acari: Tenuipalpidae) in Amazonas State, Brazil. Florida Entomologist, 94, 1073-1074. https://doi.org/10.1653/024.094.0452

SAS Institute Inc. (2003). SAS 9.1 for Windows. Cary, NC, USA.

SAS Institute Inc. (2008). JMP 8.0.2 for Windows. Cary, NC, USA.

Sayed, M. (1942). Contribution to the knowledge of Acarina in Egypt: 1. The genus Raoiella Hirst (Pseudotetranychidae: Tetranychidae). Bulletin of the Entomological Society of Egypt, 26, 81-91.

Schulten, G. G. M. (1985). Pseudo-arrhenotoky. In W. Helle, \& M. W. Sabelis (Eds.), Spider mites: Their biology, natural enemies and control (Vol. 1B, pp. 67-71). Amsterdam: Elsevier.

Sosnowska, J., \& Balslev, H. (2009). American palm ethnomedicine: A meta-analysis. Journal Ethnobiology and Ethnomedicine, 5, 43-54. https://doi.org/10.1186/1746-4269-5-43 
Stark, J. D., Tanigoshi, L., Bounfour, M., \& Antonelli, A. (1997). Reproductive potential: Its influence on the susceptibility of a species to pesticides. Ecotoxicology and Environmental Safety, 37, 273-279. https://doi.org/10.1006/eesa.1997.1552

Steege, H. ter, Pitman, N. C. A., Sabatier, D., Baraloto, C., Salomão, R. P., Guevara, J. E., ... Silman, M. R. (2013). Hyperdominance in the Amazonian tree flora. Science, 343, 1243092. https://doi.org/10.1126/ science. 1243092

Stout, M. J. (2013). Host-plant resistance in pest management. In D. Abrol (Ed.), Integrated pest management: current concepts and ecological perspective (pp. 1-21). Amsterdam: Elsevier.

Tuelher, E. S., Venzon, M., Guedes, R. N. C., \& Pallini, C. A. (2014). Toxicity of organic-coffee-approved products to the southern red mite Oligonychus ilicis and to its predator Iphiseiodes zuluagai. Crop Protection, 55, 28-34. https://doi.org/10.1016/j.cropro.2013.09.011

Valverde, P. L., Fornoni, J., \& Núñez-Farfán, J. (2001). Defensive role of leaf trichomes in resistance to herbivorous insects in Datura stramonium. Journal of Evolucionary Biology, 1, 424-432. https://doi.org/10.1046/j.1420-9101.2001.00295.x

Vásquez, C., \& Moraes, G. J. (2012). Geographic distribution and host plants of Raoiella indica and associated mite species in northern Venezuela. Experimental Applied Acarology, 60, 73-82. https://doi.org/10.1007/s10493-012-9623-0

Vásquez, C., Colmenárez, Y., \& Moraes, G. J. (2015). Life cycle of Raoiella indica (Acari: Tenuipalpidae) on ornamental plants, mostly Arecaceae. Experimental Applied Acarology, 65, 227-235. https://doi.org/10.1007/s10493-014-9858-z

Vásquez, C., Quirós, M., Aponte, O., \& Sandoval, D. M. F. (2008). Primer reporte de Raoiella indica Hirst (Acari: Tenuipalpidae) en Sur América. Neotropical Entomology, 37(6), 739-740. https://doi.org/10.1590/ S1519-566X2008000600019

Walthall, W. K., \& Stark, J. D. (1997). Comparison of two populations level ecotoxicological endpoints: The intrinsic $\left(r_{m}\right)$ and instantaneous $\left(r_{i}\right)$ rates of increase. Environmental Toxicology and Chemistry, 16, 1068-1073.

\section{Copyrights}

Copyright for this article is retained by the author(s), with first publication rights granted to the journal.

This is an open-access article distributed under the terms and conditions of the Creative Commons Attribution license (http://creativecommons.org/licenses/by/4.0/). 